\section{$\underset{\text { hommes }}{\text { \& migrations }}$}

\section{Hommes \& migrations}

Revue française de référence sur les dynamiques

migratoires

$1289 \mid 2011$

Les frontières du sport

\title{
Le voyage du directeur des ressources humaines
}

Film israélien de Eran Riklis

\section{André Videau}

\section{(2) OpenEdition \\ 1 Journals}

\section{Édition électronique}

URL : http://journals.openedition.org/hommesmigrations/823

DOI : $10.4000 /$ hommesmigrations.823

ISSN : 2262-3353

\section{Éditeur}

Musée national de l'histoire de l'immigration

\section{Édition imprimée}

Date de publication : 1 janvier 2011

Pagination : 149

ISSN : 1142-852X

\section{Référence électronique}

André Videau, «Le voyage du directeur des ressources humaines », Hommes \& migrations [En ligne], 1289 | 2011, mis en ligne le 29 mai 2013, consulté le 22 septembre 2020. URL : http:// journals.openedition.org/hommesmigrations/823 ; DOI : https://doi.org/10.4000/hommesmigrations. 823

Ce document a été généré automatiquement le 22 septembre 2020.

Tous droits réservés 


\title{
Le voyage du directeur des ressources humaines
}

Film israélien de Eran Riklis

\author{
André Videau
}

1 "Ma mission est de faire des films", proclame fièrement le réalisateur Eran Riklis. C'est vrai qu'en moins de dix ans, 8 œuvres de fiction ont jalonné sa carrière, obtenant les faveurs $\mathrm{du}$ public et remportant un succès international grâce à leur présence dans de nombreux festivals (voir La fiancée syrienne, $2004-H \& M, \mathrm{n}^{\circ}$ 1255, mai-juin 2005; Les citronniers, $2008-H \& M, n^{\circ} 1272$, mars-avril 2008). Le secret de cette réussite, pour celui qui se définit comme "cinéaste du monde", réside dans le ton composite de tragédie burlesque et de comédie dramatique que l'auteur situe au carrefour de son inspiration et de sa formation: israélienne, américaine, européenne (en l'occurrence roumaine). Cosmopolitisme bien assumé que l'on retrouve chez son interprète principal, Mark Ivanir.

2 L'adaptation à l'écran d'un roman de Abraham B. Yehoshua nous entraîne dans un road movie funèbre où le directeur des ressources humaines d'une boulangerie industrielle de Jérusalem est mandaté pour réparer un grave préjudice commis par l'entreprise à l'égard d'une employée portée disparue. En effet voilà près d'un mois que Yulia, une jeune employée roumaine au regard énigmatique de Mona Lisa, probablement immigrée clandestine, ne s'est plus présentée à son poste, sans que ses employeurs ou ses collègues s'en émeuvent. En réalité, tuée dans l'indifférence collatérale d'un attentat, son corps repose à la morgue. C'est un journaliste fouille-tout, dit "la Fouine" (Guri Alfi), qui révèle le scandale et exige réparation. Malgré ses airs sémillants, le DRH n'est pas en état de refuser la corvée. Plaqué par sa femme, moqué par sa fille, sans affinités avec ses fonctions ingrates dans l'entreprise, voilà peut-être pour lui le moyen de redorer son blason. Il est prié de rapatrier le corps dans son pays d'origine, la Roumanie, accompagné d'une enveloppe d'indemnités pour les proches (mère, enfant, ex-mari).

3 Commence alors un cortège surréaliste favorisé par une consule truculente (Rozina Cambos) qui se joue des frontières et des formalités et mobilise jusqu'à un char d'assaut 
pour transporter la dépouille. Périple initiatique où chacun, du DRH à la jolie morte en passant par le fils loubard mal aimé (Noah Silver) et le journaliste pot de colle, va découvrir sa part insoupçonnée d'humanité. 